\title{
POSTOPERAISTYCZNE SPOJRZENIE NA PRACE PRODUKCYJNĄ I NIEPRODUKCYJNĄ W NAUCE I SZKOLNICTWIE WYŻSZYM
}

\author{
KRYSTIAN SZADKOWSKI
}

\begin{abstract}
Abstrakt: W niniejszym tekście punkt wyjścia stanowi niewystarczalność teorii wywłaszczenia do analizy trwałej relacji między kapitałem wydawniczym i pracą akademicka, wobec czego koniecznościa jest rozwinięcie Marksowskiej teorii pracy produkcyjnej i nieprodukcyjnej w polu nauki i szkolnictwa wyższego. W tym celu zaproponowano postoperaistyczne spojrzenie na pracę produkcyjną, które umożliwia analizę zjawiska współczesnego podporządkowania pracy akademickiej kapitałowi, jak również prowadzony względem niego opór. Istotę tego podejścia najłatwiej określić poprzez ekspozycję dwustronnej perspektywy na Marksowskie kategorie z zakresu krytyki ekonomii politycznej. Została ona tu wykorzystana do przybliżenia koncepcji bezpośrednio produkcyjnej pracy akademickiej, jak również wskazania na jej wyraźne ograniczenia, w kolejnym zaś kroku do prezentacji systemowego ujęcia produkcyjności pracy akademickiej. Tylko w ten sposób bowiem można postawić kwestię prawdziwie produkcyjnej pracy akademickiej w sensie Marksowskim oraz blokad stojących na drodze do jej pełnej realizacji, z których kluczowa jest niezakłócone funkcjonowanie kapitalistycznej miary w obszarze nauki i szkolnictwa wyższego.
\end{abstract}

Słowa kluczowe: kapitał, praca produkcyjna i nieprodukcyjna, praca akademicka, szkolnictwo wyższe, Marks 


\section{Wprowadzenie}

W styczniu 2012 roku amerykański matematyk Timothy Gowers postanowił upublicznić swoją decyzję o bojkocie czasopism wydawanych przez firmę Elsevier. Tak powstała strona „The Cost of Knowledge"1, na której wyjaśniano powody wstrzymywania się od publikowania, recenzowania czy redagowania publikacji z czasopism wydawanych przez tę firmę oraz zbierano podpisy pod deklaracja. Sprzeciw wzbudziły przede wszystkim zaporowe ceny za dostęp do publikacji i ogromne zyski generowane przez komercyjnych wydawców w oparciu o bezpłatną pracę naukowców. W ciagu kilku miesięcy do protestu dołączyły tysiące pracowników naukowych, głównie przedstawicieli świata matematyki i nauk ścisłych, a Elsevier nie tylko odczuł skutki tego bojkotu finansowo ${ }^{2}$, ale również przedsięwziął szereg działań mających na celu złagodzenie wzburzenia ludzi nauki ${ }^{3}$. Choć sprawa odbiła się dużym echem i doczekała się licznych komentarzy, to już sam inicjalny manifest może posłużyć za soczewkę skupiającą interesującą nas w tym artykule problematykę.

W kolejnych krokach, w tekście na stronie wyjaśniono: a) zmiany, jakie zaszły w zakresie upowszechniania wiedzy i roli, jaką w tym procesie pełnią czasopisma naukowe; b) ciężką do zastąpienia funkcję pełniona przez czasopisma w procesie ewaluacji dorobku naukowego; c) rolę firmy Elsevier w obecnym kryzysie; d) przyczyny bojkotu; oraz e) horyzont dalszych działań ukierunkowanych na wprowadzenie nowego modelu funkcjonowania komunikacji naukowej. W każdym z tych elementów charakteryzowano nadużycia, których dopuszcza się adresat bojkotu bądź te, które są konsekwencją anachroniczności oferowanych przez wydawcę rozwiązań.

Zarysowany w omawianym tekście obraz produkcji naukowej podkreśla istotność bezpłatnej pracy akademików odbywającej się na każdym etapie produkcji, jak również niezbędność tej samej akademickiej klienteli dla realizacji zysków przez wydawnictwo. Innymi słowy, naukowcy opłacani z publicznych środków zarówno wytwarzaja produkt początkowy, samodzielnie go obrabiaja (w tekście wskazuje się na znaczenie zmiany technologicznej umożliwiającej samodzielne opracowywanie skomplikowanych tekstów matematycznych przy użyciu cyfrowych czcionek - czynność, która wymagała do tej pory dużej pracy i nakładów ze strony wydawcy), pełnią funkcję recenzentów nadsyłanych prac, a następnie te same,

\footnotetext{
${ }^{1}$ http:/ / thecostofknowledge.com/

${ }^{2}$ W swojej ekspertyzie bank Exane Paribas wskazał na skutki finansowe, jakie w bezpośrednim następstwie inauguracji bojkotu poniosła notowana giełdowo spółka Reed-Elsevier. Zob. (Storbeck 2012).

${ }^{3} \mathrm{~W}$ serii listów do wspólnoty matematyków firma Elsevier informowała o konsekwentnie prowadzonych działaniach mających na celu z jednej strony istotne obniżenie kosztów publikowanych prac, z drugiej zaś wspomożenie światowej wspólnoty matematyków w rozwijaniu ich dyscypliny (poprzez fundowanie nagród, stypendiów czy rozszerzanie bezpłatnego dostępu do klasycznych prac z dyscypliny). Zob. https://www.elsevier.com/physical-sciences/mathematics/open-letters-to-the-mathematics-community
} 
zatrudniające ich instytucje płacą za możliwość uzyskania dostępu do wyników badań opłaconych wcześniej ze środków publicznych. Jako kluczowy bodziec oddziałujący na chęć pracowników do podejmowania się bezpłatnych działań na rzecz kapitalistycznego wydawcy wskazano splot etosu właściwego akademii z odgrywaniem coraz istotniejszej pozycji przez czasopisma wydawane przez tych wydawców w krajowych i instytucjonalnych procedurach ewaluacji. Innymi słowy, problem, który za tym stoi, to zachodzące przesunięcie od procedur ewaluacji do procedur waloryzacji, od właściwych dla pola nauki procedur oceny i krytyki do procedur szacowania wartości czy quasi-wartości.

Choć głównym punktem odniesienia omawianego manifestu jest dziedzina nauk matematycznych, to ogólna charakterystyka problemów pracowników naukowych z wydawcami czasopism naukowych da się ekstrapolować na inne obszary wiedzy. Opór części środowiska naukowego zrodził się bowiem z braku racjonalnej odpowiedzi na pytanie, dlaczego w obliczu systematycznie spadających kosztów produkcji i upowszechniania artykułów naukowych, przy jednoczesnym istotnym opieraniu się na wszystkich etapach produkcji na darmowej pracy naukowców na całym świecie, ceny za poszczególne artykuły, jak również za pakiety subskrypcji czasopism sprzedawanych przez wydawcę, sa nieproporcjonalnie wysokie do ponoszonych kosztów. Porównywalne w swej irracjonalności tylko z zyskami czerpanymi przez tych wydawców ${ }^{4}$. Sygnatariusze i sygnatariuszki listu podkreślają tą irracjonalną asymetrię pisząc: „Elsevier, Springer i liczni inni wydawcy komercyjni [...] wyzyskuja naszą dobrowolną pracę w celu wydobywania ogromnych zysków ze wspólnoty naukowej. Dostarczają jaką́s wartość w ramach procesu, jednak nie taka, która uzasadniłaby stosowane przez nich ceny” 5 .

W przytoczonym fragmencie manifestu przedstawiony konflikt przywodzi na myśl antagonizm zachodzący między pracą i kapitałem. Jednak realia nie pozwalają na mówienie o niej w kategoriach wyzysku w proponowanym przez Marksa sensie. Z jednej strony, choć pracownicy akademiccy (zatrudnieni najczęściej formalnie w instytucji publicznej) zostają ograbieni z rezultatów własnej pracy, jednocześnie przyczyniają się nie tylko do akumulacji, ale

\footnotetext{
${ }^{4}$ Szacuje się, że rynek wydawnictw akademickich wart jest około 10 mld dolarów rocznie (Ware i Mabe 2015). Zyskowność tego przedsięwzięcia można przybliżyć, wskazując na poziom marż operacyjnych, które generują najwięksi wydawcy. Mówi się tutaj o przedziale między 20 a 30\%, czy nawet 40\%. Christian Fuchs i Marisol Sandoval wyliczyli wskaźnik ,stopy zysku” na podstawie danych finansowych wybranych wydawców akademickich za rok finansowy 2012 (dla firmy Springer 2011). Średnio wynosiła ona 18,2\%. Reed-Elsevier 21,7\%; Springer 20,2\%; Taylor \& Francis 24,9\%; Wiley-Blackwell 12,4\%; Wolters Kluwer 15,2\% (Fuchs i Sandoval 2013, 429). Beverungen i jego współpracownicy, którzy przytaczają inne dane (dla 2010 roku, sugerujące marże zysku na poziomie 35,7\% dla spółki Reed-Elsevier czy 33,9\% dla Springera) odnoszą się również do dobrze znanej, jednak wciąż pouczającej ekspertyzy o istocie rynku wydawnictw akademickich sporządzonej przez Deutsche Bank: „Jesteśmy przekonani, że wydawcy dodają względnie niewielką wartość do procesu wydawniczego. Nie chcemy przez to zapominać o tym, w jaki sposób 7000 ludzi zatrudnionych w spółce Reed-Elsevier zarabia na chleb. Zauważamy jedynie, że jeżeli proces byłby rzeczywiście tak złożony, kosztowny i przynoszący wartość dodana, jak upiera się przy tym wydawca, poziom blisko $40 \%$ marży byłby zwyczajnie niemożliwy" (Beverungen, Böhm i Land 2012, 931).
}

${ }^{5}$ http://thecostofknowledge.com/ 
też regularnego pomnażania kapitału wielkich wydawnictw, dlatego ciężko mówić o akumulacji przez wywłaszczenie czy alienacji (Peekhaus 2012). Mamy tu do czynienia z procesem stałego, cyklicznego wywłaszczania - przypominającego w ten sposób stosunek wyzysku, tzn. regularnego ograbiania z pracy dodatkowej bez wypłacania ekwiwalentu. Zasób, który jest „wywłaszczany” (wiedza zamykana we własnościowej postaci towaru-artykułu) jest szybko odtwarzany i sytuacja powtarza się niejako stale od nowa. Większość pracowników poddaje się tej procedurze „dobrowolnie” (nie mając innego wyjścia - często będąc przymuszonym przez sztywne procedury krajowej bądź instytucjonalnej ewaluacji). Z drugiej strony, nie można im również z łatwością przypisać statusu pracowników produkcyjnych, przynajmniej nie posługując się wulgarnie rozumianą teorią pracy produkcyjnej i nieprodukcyjnej, według której produkcyjny jest ten, kto pracuje w stosunku pracy najemnej, w stricte kapitalistycznym przedsiębiorstwie wytwarzającym materialne towary.

W tym tekście wychodzę od zarysowanego powyżej napięcia: między niewystarczalnością teorii alienacji czy wywłaszczenia do analizy trwałej relacji między kapitałem i praca akademicką w kontekście wydawnictw akademickich a koniecznościa rozwinięcia Marksowskiej teorii pracy produkcyjnej i nieprodukcyjnej w taki sposób, ażeby precyzyjniej uchwytywała relację zachodzącą między kapitałem a pracą akademicką w polu szkolnictwa wyższego. W to miejsce postaram się zaoferować postoperaistyczne spojrzenie na akademicką pracę produkcyjną, licząc, że uda mi się zarówno rozwinąć teorię marksistowską, jak też wnieść swój wkład w analizę zjawiska współczesnego podporządkowania pracy akademickiej kapitałowi (zob. Szadkowski 2015, 111-223). Warto podkreślić, że zależy mi tym samym również na rozszerzeniu potencjału wspólnej mobilizacji pracowników akademickich z innymi warstwami klasy robotniczej - buntujących się wobec narzucaniu i egzekwowaniu produkcyjności ich pracy przez kapitał.

Niniejszy tekst składa się z siedmiu części, z czego pierwszą stanowiło niniejsze wprowadzenie. Na druga część składa się zwięzły przegląd literatury marksistowskiej dotyczącej rozróżnienia na pracę produkcyjna/nieprodukcyjna. Przedstawiam w nim interpretacje ekonomiczne oraz polityczne, i na ich tle lokuję perspektywę postoperaistyczną. W trzeciej części wskazuje na nieustanną aktualność dynamicznego i historycznego Marksowskiego rozumienia pary pojęć praca produkcyjna/nieprodukcyjna. Dowodzę, że powracająca do korzeni lektura tego rozróżnienia jest wciąż w stanie wyposażyć nas w narzędzia do rozumienia zmieniających się realiów kapitalistycznej produkcji rozciagniętej również na sektor szkolnictwa wyższego i nauki. Część czwarta zarysowuje dwoiste rozumienie tytułowego rozróżnienia, ukazując zarówno pracę produkcyjna/nieprodukcyjną z perspektywy kapitału, jak i z perspektywy klasy robotniczej (to znaczy zaangażowaną bądź nie w produkcje tego, co wspólne). Część piąta zawiera zwięzłą krytykę ujmowania produkcyjności pracy akademickiej w sposób bezpośredni (w pojedynczym zakładzie pracy/produkcji akademickiej), otwierając 
drogę dla rozważań zawartych w kolejnej części dotyczącej systemowego ujmowania produkcyjności pracy akademickiej. Ostatnia, siódma część zawiera wnioski i podsumowanie, sprowadzając dyskusję na grunt produkcyjności komunistycznej, to znaczy warunków wytwarzania tego, co wspólne przez pracę akademicką. Zanim jednak przejdę do kolejnych części, postaram się jeszcze wyraźniej zarysować najistotniejszy węzeł problemowy, z którym zmierzyć musi się niniejszy tekst.

\subsection{Węzeł problemowy}

Gdy przyjrzymy się współczesnej pracy akademickiej, redukując ją na potrzeby tej analizy wyłącznie do wymiaru pracy naukowej, staniemy przed troistym problemem. Po pierwsze, autonomiczną podstawę jej egzystencji i rozwoju stanowią odwieczne, swoiste dla pola naukowego, praktyki komunikacyjne (Clark 2006). Pracownicy akademiccy prowadzą badania i ogłaszają ich rezultaty, chcąc dotrzeć do specyficznej grupy specjalistów lub jak najszerszego grona odbiorców. Znajdziemy ich na każdym etapie tego procesu jednocześnie jako twórców oceniających i nadzorujących publikację efektów końcowych, jak również pośród ich głównych odbiorców. Co więcej, na każdym etapie pracy akademickiej ich wysiłki zdają się być wynagradzane czymś innym niż po prostu finansowa walutą - akademickim prestiżem, uznaniem wspólnoty uczonych (Blackmore i Kandiko 2011; Bourdieu 1984). Co prawda często potrzebują wsparcia ze strony instytucji publicznych, niekiedy utrzymują się też w oparciu o inne źródła przychodów czy pomoc patronów, rodzin lub sieci towarzyskich. Mając zaspokojone podstawowe potrzeby oraz opłacone koszty własnej aktywności (dostęp do książek i artykułów, aparaturę badawczą, nieskrępowane możliwości wymiany myśli, swobodę przemieszczania się i uczestnictwa w konferencjach, itd.), mogą oddawać się produkcji i upowszechnianiu wiedzy nie roszcząc sobie pretensji do dodatkowego wynagrodzenia za efekty swojej pracy. Ta wyidealizowana wizja praktyki komunikacji naukowej stanowi oczywiście tylko część bardziej złożonego obrazu.

Po drugie, przynajmniej od czasów prac Dereka De Solli Price'a (1967) widzimy wyraźnie, jak przedsięwzięcie naukowe rozrasta się, praca naukowa przyspiesza (Vostal 2015), a w jej najbliższym otoczeniu pojawiają się aktorzy, którzy z samym rozwojem nauki nie maja bezpośrednio nic wspólnego. Nie chodzi przy tym wyłącznie o rosnącą rolę państwa w regulacji i nadzorze systemów nauki i szkolnictwa wyższego (Neave 2012). Choć rośnie znaczenie praktyk komunikacji naukowej w organizacji systemów nauki i szkolnictwa wyższego na poziomie narodowym, to momentem przełomowym w intensyfikacji kontroli produktywności badawczej pracowników akademickich jest moment ukonstytuowania się globalnych rankingów uniwersytetów (Marginson 2009; Hazelkorn 2011). Wydarzenie to przyczyniło się do upowszechnienia konkurencji między instytucjami i wewnątrz instytucji szkolnictwa 
wyższego na niespotykaną dotychczas skalę, zaostrzając ją z każdym rokiem swojego niemal niezakłóconego funkcjonowania (Shore i Wright 2015). Niemniej już od końca dziewiętnastego wieku czyniono starania, by niezwykle heterogeniczne formy komunikacji naukowej, stanowiące dziś główne paliwo „silników” napędzających globalne rankingi, ująć w karby i umożliwić nie tylko ich kontrolę (Godin 2006, 2007), ale również stały nadzór nad ich rozwojem, rozrostem i efektywnością (Godin 2009).

Po trzecie, mamy do czynienia ze ściśle splecionym z powyższymi zjawiskami, wykładniczym przyspieszeniem akumulacji kapitału przez duże, akademickie firmy wydawnicze, które w skutek procesu dynamicznych konsolidacji urastają do pozycji stabilnych oligopoli (Larivière i in. 2015). Towarzyszy temu wzmacnianie pozycji różnorodnych dostawców metryk służących do pomiaru i wartościowania publikacji naukowych (Wilsdon i in. 2015). Przywołana na początku tego artykułu firma Elsevier łączy obie te funkcje: z jednej strony, jako wydawca akademicki oferując szeroka paletę czasopism naukowych, z drugiej zaś, prowadząc bazę indeksująca tego rodzaju czasopisma (Scopus) i dostarczając metryk, wskaźników i metadanych zarówno dla własnych produktów rankingowych, jak i ogólnie dla dostawców globalnych rankingów czy realizatorów praktyk ewaluacyjnych. Wydaje się tym samym, że firma Elsevier w swojej relacji z globalna praca akademicką jest jednym z istotnych beneficjentów przekształcania konkurencji o wyniki w dziedzinie poznania między pojedynczymi badaczami w konkurencję między uniwersytetami czy całymi krajami. Rywalizacja ta dotyczy miejsca w tym lub innym zestawieniu, pozycji w swoistym, „akademickim wyścigu zbrojeń” (Kehm 2013; Münch 2013, 2014; Dill 2009).

Trzy powyższe wątki splatają się w jeden węzeł problemowy wzajemnej relacji między pracą akademicką (rozumianą wąsko, wyłącznie w ramach jej aktywności badawczopublikacyjnej) a kapitałem, na który więcej światła może rzucić próba ujęcia go w Marksowskich kategoriach pracy produkcyjnej i nieprodukcyjnej.

\section{Dyskusja o pracy produkcyjnej/nieprodukcyjnej na gruncie współczesnego marksizmu}

Zdolność do rozróżniania na pracę produkcyjną i nieprodukcyjna stanowi fundament sprawnie działającej gospodarki, w której dominuje kapitał. Wiedział o tym doskonale Karol Marks, podejmując tę kwestię parokrotnie, przede wszystkim w swoich szkicach ekonomicznych (zob. Marks 1959, 1986, 2013) mających się złożyć następnie na Kapitał.

Dyskusja nad istotą tego rozróżnienia trwa od lat (zob. Rubin 1990; Gough 1976; Meiksins 1981) i wciąż nie traci na znaczeniu (Duménil i Lévy 2011; Roberts 2014; Pitts 2015a, 2015b; Ratajczak 2015). Tak, jakby stwierdzenie funkcjonalności czy przestarzałości tej pary 
stanowiło podstawowe zadanie, z jakim zmierzyć powinien się każdy kontynuator dzieła Marksa chcący powiedzieć cokolwiek o pracy i produkcji w warunkach współczesnego kapitalizmu. W tej dyskusji ton nadaja przede wszystkim strategiczne interpretacje ekonomiczne prowadzone z perspektywy kapitału (w rozumieniu Cleavera 2012, 49-51). Tego rodzaju analizy przede wszystkim cyzeluja kategorie i podziały w gospodarce kapitalistycznej; w ostatecznym rozrachunku ich celem jest przedstawienie takiego obrazu tego, co produkcyjne/nieprodukcyjne, który uchroniłby posługującą się nimi Marksowską teorię wartości przed miażdżąca krytyką (por. Savran i Tonak 1999, 133; 147 czy szczególnie topologiczne, trójwymiarowe i złożone podejście zaprezentowane w Robertson 2014, 339). Ta pojęciowa para bywa zatem zarówno definitywnie odrzucana, jako niewnosząca nic analitycznie istotnego do zrozumienia produkcji kapitalistycznej. Zakłada się bowiem, że wszyscy robotnicy zatrudniani przez kapitał wytwarzają wartość dodatkową (por. Houston 1997, Leibman 1999). Z drugiej zaś strony, znajduje równie zaciekłych obrońców (por. Mohoun 1996, 2002). Mohoun (1996) zasadnie stwierdza, że pozbawiony tego rozróżnienia aparat pojęciowy Marksa (jeśli zredukować go na chwilę, jak chcą tego ekonomiści, do teorii wartości i wartości dodatkowej) traci całkowicie swoją analityczną użyteczność, z tego powodu zadaniem stojącym przed każdym marksistowskim ekonomista politycznym jest systematyczne odrzucanie zarzutów, że wspiera się ona na metafizycznej podstawie. Niektórzy słusznie jednak wskazuja, że nie tyle Marksowskie pojęcia obciążone są metafizycznie, co kapitał jako źródło wszelkiej transcendencji w polu produkcji nie jest w stanie ugruntować produkcyjności pracy inaczej niż poprzez metafizyczne określanie tego, co produkcyjne i nieprodukcyjne (Ratajczak 2015, 97).

Drugi istotny nurt w tej toczącej się od lat dyskusji stanowią interpretacje polityczne, których autorzy za swój cel obierają takie ujęcie pary produkcyjne/nieprodukcyjne, które pozwoliłoby na najskuteczniejsze prowadzenie walki klasowej. Jeśli skuteczny opór w kapitalizmie prowadzą robotnicy produkcyjni - to na nich bowiem wspierać się ma proces wytwarzania wartości dodatkowej dla kapitału - wówczas dowiedzenie, że każda praca ma lub może mieć produkcyjny charakter dla kapitału pozwala na otworzenie walki z nim na jak najszerszą grupę wytwórców (zob. Lebowitz 2003; Harvie 2004, 2005; Negri 2014). Przykładem takiego rozszerzania kategorii pracy produkcyjnej jest ujęcie w jej ramach nauczycieli (również akademickich) zatrudnionych w sektorze publicznym, za które odpowiada David Harvie (2006). Harvie twierdzi, że jego zamiarem nie jest pozostawanie w logicznej zgodności z pismami Marksa - wydaje się mu to wręcz niemożliwe - uważa bowiem, że jego własna perspektywa jest dużo bardziej użyteczna w rozumieniu procesów, w ramach których nauczyciele produkuja i reprodukuja kapitalistyczne stosunki społeczne - wskazując na potencjalną siłę nauczycieli do zerwania tej (re)produkcji. Nauczyciele są według niego pracownikami produkcyjnymi, o tyle, o ile poddani są wyalienowanej pracy, do której efektów przykładana jest kapitalistyczna miara (Harvie 2006, por. częściowo przekonujące rozwinięcie 
tego argumentu w kontekście brytyjskiego RAE, De Angelis i Harvie 2006). Inne podejście rozwiną Michael A. Lebowitz w swojej pracy Beyond Capital: Marx's Political Economy of the Working Class. Kanadyjski marksista twierdzi, że ekonomiczne dyskusje poświęcone interesującej nas parze pojecć wskazują na daleko idąca jednostronność tych marksistowskich odczytań (Lebowitz 2003, 133-136). Fetysz obiektywistycznego ujmowania kapitalistycznych procesów zaciemnia polityczny wymiar Marksowskich kategorii, tak jakby Marks rozwijał projekt ekonomii politycznej kapitalizmu, a nie jej krytyki. W istocie praca może być również produkcyjna i nieprodukcyjna z punktu widzenia potrzeb robotniczych - perspektywy ich rozwoju i stwarzania coraz to nowych możliwości ich zaspokajania. Tego typu ujęcia wskazują zatem na dwustronność i polityczność kategorii pracy produkcyjnej/nieprodukcyjnej, do których jeszcze wrócimy.

Marksiści orientacji operaistycznej i postoperaistycznej, których intuicje w niniejszym tekście chciałbym zaaplikować do pola badań nad szkolnictwem wyższym, umieszczani są najczęściej w drugiej z zarysowanych powyżej stron debaty. Ze swoim podejściem kwestionującym większość fundamentalnych Marksowskich rozróżnień i pojęć wzbudzają jednak powszechne wątpliwości i polityczne kontrowersje. Najczęściej krytykowanym autorem jest tutaj Antonio Negri (zob. Caffentzis 2005, De Angelis 2005, Kicillof i Starosta 2007), który w latach siedemdziesiątych XX wieku, jak i w późniejszym okresie współpracy z Michaelem Hardtem (Hardt i Negri 2005) i formułowania teorii biopolitycznej produkcji (Hardt i Negri 2012), odrzucił to rozróżnienie jako przestarzałe i wykorzystywane przez tych, którzy pragną przyprawić Marksowi „gębę” starego, dziewiętnastowiecznego materialisty (zob. Negri 2014). Część intuicji postoperaistycznych wydaje się jednak znacznie lepiej opisywać to, w jaki sposób kształtują się relacje zachodzące między pracą a kapitałem oraz to, jakie trudności napotyka (i jak je przezwycięża) kapitał, usiłując narzucić produkcyjność pracy w niektórych sektorach gospodarki, niż wskazywałyby na to zjadliwe krytyki ich zaciekłych przeciwników. Uważam, że pójście dwoma ścieżkami wyznaczanymi przez intuicje postoperaistów, to znaczy dostarczanym przez nich wglądem w przemiany sektora produkcji i stosunków, w jakie wchodzi w nim praca i kapitał (Pasquinelli 2009, 2014a, 2015), jak również za ich politycznymi postulatami (Negri 2014, Harvie 2005), pozwala na sensowniejsze, z punktu widzenia analizy i praktyki politycznej, ujmowanie dzisiejszych zmian w sektorze szkolnictwa wyższego i nauki. Rozwinę oba te wątki w dalszych częściach tekstu.

\section{Marks i praca produkcyjna/nieprodukcyjna}

Większą cześć swoich analiz pojęcia i zjawiska pracy produkcyjnej i nieprodukcyjnej Marks zawarł w nieopublikowanych za życia szkicach swojego wielkiego projektu: w Zarysie krytyki ekonomii politycznej, Teoriach wartości dodatkowej czy Rezultatach beapośredniego procesu produkcji. 
Najrozleglej do tematu podszedł w pierwszej księdze Teorii wartości dodatkowej, gdzie odnosząc się do ustaleń klasyków ekonomii politycznej (na czele z Adamem Smithem), wskazał na trzy najbardziej podstawowe określenia pracy produkcyjnej w ramach kapitalistycznego sposobu produkcji. Produkcyjna jest zatem według niego ta praca, która: a) wymienia się na kapitał; b) realizuje się w towarze; oraz c) tworzy wartość dodatkową. Określenia a) i b) zaczerpnął (ze znacznymi modyfikacjami) właśnie od autora Bogactwa narodów. I tak, pierwsze z nich uzależnia produkcyjność jedynie od relacji pracy z kapitałem (niezależnie od jej materialnej formy), drugie zaś podkreśla znaczenie formy towarowej wytworów pracy. Trzecie określenie posiadało dla Marksa szczególne znaczenie, ponieważ umieściło pracę produkcyjną w centrum jego teorii wartości dodatkowej, a tym samym również u podstaw jego projektu politycznego - klasowej walki o zniesienie kapitalizmu.

Przywołajmy w tym miejscu in extenso definicję otwierająca rozważania z pierwszego tomu Teorii wartości dodatkowej: „Z punktu widzenia produkcji kapitalistycznej produkcyjna jest ta praca najemna, która przy wymianie na zmienną cześć kapitału nie tylko reprodukuje tę część, lecz wytwarza ponadto wartość dodatkową dla kapitalisty" (Marks 1959, 144). „Produkcyjna jest tylko ta praca, która produkuje kapitał” (Marks 1959, 144), a to znaczy, jak zgrabnie sformułowano to w Zarysie krytykei ekonomii politycznej, że „Praca jest produkcyjna tylko wówczas, gdy tworzy swoje przeciwieństwo" (Marks 1986, 222). W tym fragmencie rozważań Marksa cechą charakterystyczną procesu pracy produkcyjnej jest jej udział w procesie pomnażania kapitału, występowanie w ramach stosunku pracy najemnej, jak również to, że realizuje się ją bez właściwego ekwiwalentu przypadającego w udziale robotnikowi. W Rezultatach Marks podkreśla, że praca taka bezpośrednio wytwarza wartość dodatkową oraz bezpośrednio służy jako czynnik procesu samopomnażania wartości. W Teoriach wartości dodatkowej pisze dalej, że: „Produkcyjna jest zatem - w systemie produkcji kapitalistycznej taka praca, która wytwarza wartość dodatkową dla tego, co ją zatrudnia, czyli inaczej mówiąc, taka praca, która obiektywne warunki pracy przekształca na kapitał, a jej posiadacza - na kapitalistę; jest to praca, która własny swój produkt wytwarza jako kapitał” (Marks 1959, 416). Antagonistyczny wymiar tego stosunku podkreślany jest w kolejnym kroku, gdzie Marks stwierdza, że „produkcyjna jest taka praca, która dla robotnika odtwarza tylko uprzednio określoną wartość jego siły roboczej, która jednakże jako czynność tworząca wartość pomnaża kapitał czyli praca, która samemu robotnikowi przeciwstawia pod postacia kapitału wartości przez siebie stworzone" (Marks 1959, 417).

Możemy wypracować jeszcze precyzyjniejszą definicję pracy produkcyjnej, wskazując za Marksem na cechy charakterystycznych kapitalistycznego procesu produkcji. W Rezultatach wyróżnia on dwa czynniki odpowiadające za produkcyjność danego procesu pracy: posiadacz siły roboczej zostaje przeciwstawiony kapitaliście jako sprzedawca żywej pracy posiadający status pracownika najemnego, a następnie zostaje wcielony jako żywy czynnik wchodzący 
w miejsce wartości kapitału zmiennego do procesu produkcji (jego praca zostaje uprzedmiotowiona). Według Marksa każdy robotnik produkcyjny jest pracownikiem najemnym, jednakże nie każdy pracownik najemny będzie z samego tego faktu robotnikiem produkcyjnym. Autor Kapitału zwraca uwagę, że ogromna ilość czynności, funkcji i aktywności, które do tej pory (do jego czasów, a dziś moglibyśmy prawdopodobnie wymienić więcej przykładów) były uznawane za cele same w sobie i wykonywane nieodpłatnie lub zapłata za ich wykonywanie była dostarczana pośrednio, przekształca się na skutek rozwoju i dominacji produkcji kapitalistycznej w czynności wykonywane w reżimie pracy najemnej, a ich wartość zaczyna być szacowana i mierzona według zasad wyceny pracy najemnej. Niemniej samo utowarowienie danej czynności nie jest warunkiem wystarczającym, aby traktować ja jako produkcyjna. Sprawia to, że te dwa modusy pracy często są ze sobą mylone - koniecznym do spełnienia kryterium jest wobec tego włączenie danej aktywności w proces produkcji wartości dodatkowej w charakterze żywego czynnika.

Żywy czynnik produkcji zostaje uspołeczniony wraz z wkroczeniem do produkcji. Marks pisze w Kapitale: „Pojęcie robotnika produkcyjnego zawiera więc nie tylko stosunek między działalnością a efektem użytkowym, między robotnikiem a produktem pracy, lecz również swoiście społeczny, historycznie powstały stosunek produkcji, który na robotniku wyciska stempel środka służącego bezpośrednio pomnażaniu wartości kapitału” (Marks 1968, 602). Produkcyjny robotnik dla kapitału stanowi zatem przede wszystkim środek do tworzenia wartości dodatkowej będącej istotą kapitału - jego początkiem, jego nieustannym pragnieniem i obiektem pożądania. Społeczny stosunek zachodzacy między pracą a kapitałem to stosunek produkcyjności.

Inaczej rzecz się ma z pracą nieprodukcyjna. Tu wskazania Marksa mogą się wydać nieco bardziej arbitralne. Marks jako nieprodukcyjne wskazuje trzy rodzaje pracy. Po pierwsze, pracę, której efektem jest reprodukcja siły roboczej - tego specjalnego towaru, który stanowi podstawę wytwarzania wartości dodatkowej w kapitalizmie. Bez tego arbitralnego wykluczenia nie tylko rama analityczna pozwalająca na uchwytywanie produkcji wartości dodatkowej w kapitalizmie uległaby załamaniu, ale przede wszystkim zachwiałaby się podstawa kapitalistycznej gospodarki. Drugą nieprodukcyjną praca jest nadzór nad praca innych (np. kontrolowanie samodzielnie wykonujących pracę pracowników) odróżniony przez Marksa od pracy związanej z organizacja pracy innych - dostarczaniem schematów kooperacji itd. Trzecim rodzajem nieprodukcyjnej aktywności w gospodarkach, w których panuje kapitalistyczny sposób produkcji, są według autora Kapitału te zaangażowane w sferę cyrkulacji ${ }^{6}$. Tu również

\footnotetext{
${ }^{6}$ Inaczej twierdzi inspirujący się pracami autorów tzw. Neue Marx Lekture Frederick H. Pitts (2015a, 2015b), który argumentuje, że ze względu na nieodłączność procesu realizacji wartości dodatkowej również aktywności przyspieszające proces cyrkulacji (zbytu towarów - w rodzaju np. reklamy) maja dla kapitału produkcyjny charakter. Brytyjski badacz twierdzi wręcz, że jedynie z punktu widzenia cyrkulacji (niejako zwrotnie) można bez
} 
Marks dokonuje pewnego arbitralnego zdawałoby się wykluczenia: transport i wszystko z nim związane jest aktywnością produkcyjna. Jak prorocze okazały się te intuicje pokazuje dynamiczny rozwój i kluczowe znaczenie logistyki dla przepływów wartości we współczesnym kapitalizmie (Mezzadra i Nielson 2013).

Praca nieprodukcyjna to zatem taka aktywność, która pomimo odbywania się w formie pracy najemnej wymienialna jest na dochód, czyli taka, która nie przyczynia się do bezpośredniego wytwarzania wartości. W przypadku pracy nieprodukcyjnej działa swego rodzaju prawo wartości, wartość usług określana jest społecznie niezbędnym czasem pracy, wartość nieprodukcyjnej siły roboczej określana jest przez koszty jej reprodukcji, tak samo jak produkcyjnej siły roboczej. Nieprodukcyjni pracownicy moga także wykonywać pracę dodatkowa, to znaczy pracować ponad wypłacany im ekwiwalent.

Wreszcie, sprawa pogarsza się, gdy do powyższego obrazu dodamy problem stopniowego rozszerzania się pojęcia i zjawiska produkcyjności pracy, które towarzyszy komplikowaniu się kapitalistycznego przedsięwzięcia produkcyjnego. W Zarysie, jak również w Kapitale Marks wskazuje na niewystarczalność bezpośredniego ujmowania pracy produkcyjnej. Wiąże tam rozszerzenie skali kooperacji w kapitalizmie $\mathrm{z}$ modyfikacja produkcyjnego charakteru pracy, pisząc: „A zatem wraz z rozwojem kooperacyjnego charakteru procesu pracy rozszerza się siłą rzeczy pojęcie pracy produkcyjnej i jej przedstawiciela, robotnika produkcyjnego. Ażeby pracować produkcyjnie, nie trzeba już teraz samemu przykładać ręki. Wystarczy być organem robotnika łącznego i pełnić którąkolwiek z jego podfunkcji." (Marks 1968, 603). Kapitalistyczna produkcyjność, przy odpowiednim stopniu rozwoju społecznej produkcji, rozlewa się zatem po całej fabryce.

\subsection{Historyczna i polityczna określoność pracy produkcyjnej i nieprodukcyjnej}

Podział na pracę produkcyjną i nieprodukcyjną u Marksa ma zatem charakter formalny i dynamiczny. Jest uzależniony od sieci relacji, w które wplątana jest dana aktywność. Jak zauważył już Izaak Rubin, Marks trzymając się konsekwentnie swojej metody, „odrzucił jako kompletnie bezużyteczne pytanie o to, jakiego rodzaju praca jest produkcyjna w ogólności, we wszystkich epokach historycznych, niezależnie od danych stosunków społecznych" (Rubin 1990, 259). Jego intuicje, które tak czytelnie zostały wyłożone na początku rozdziału o procesie pracy i procesie pomnażania wartości w pierwszym tomie Kapitału (Marks 1968), dobrze odczytał Bruno Gulli (2005), twierdząc, że kategoria pracy rozwinięta przez ekonomię polityczną kapitalistycznego sposobu produkcji nie odpowiada temu, czym jest praca jako taka, jej pojęciu. Praca jest produkcyjna lub nieprodukcyjna - ale jak zaznacza - dla kapitału i kiedy

szkodliwego esencjalizowania określić, które czynności w obszarze produkcji miały charakter właściwie produkcyjny. 
funkcjonuje w jego ramach. Gulli wprowadza pojęcie ani-produkcyjnej-ani-nieprodukcyjnej pracy lub pracy ani/ani - czyli pracy w jej neutralności, by oddać to, co stoi na ontologicznym planie za Marksowską dyskusją o pracy produkcyjnej/nieprodukcyjnej. Określenie danej aktywności w ramach tej opozycji zachodzi zawsze w konkretnych historycznych warunkach produkcji, a w gospodarce, w której dominuje kapitalistyczny sposób produkcji decydującą rolę w tym procesie wydaje się odgrywać kapitał.

Z założenia o wyjściowo neutralnym produkcyjnie statusie pracy wynika poważna konsekwencja. Jak pisze Marks w Teoriach wartości dodatkowej, „bycie praca produkcyjna jest określeniem pracy, które w sobie i dla siebie nie ma absolutnie nic wspólnego z określona treścia pracy, jej szczególną przydatnością, czy też właściwą wartością użytkową, w której się ona prezentuje.”. Mówiąc inaczej, ta sam praca, aktywność o tej samej treści, np. prowadzenie badań, może być zarówno produkcyjna, jak i nieprodukcyjna (Marks 1959, 420). Decyduje o tym konkretny stosunek, w którym wydatkowana praca znajduje się względem kapitału. O przydatności danej pracy produkcyjnej dla kapitału decyduja jednak nie tyle, „jej określone pożyteczne właściwości, podobnie jak nie stanowią o niej szczególne pożyteczne cechy produktu, którego postać praca przybrała, lecz właściwości pracy jako twórczego elementu wartości wymiennej, jej cecha jako pracy abstrakcyjnej. Przy czym nie chodzi o to, że praca reprezentuje w ogóle pewną określoną ilość pracy ogólnej, lecz o to, że reprezentuje ilość wiekeszq, niż zawarta w jej cenie, to znaczy w wartości sity roboczej” (Marks 1959, 420)

Przyglądając się temu problemowi z zarysowanej powyżej perspektywy, wyraźnie dostrzegamy zamysł Marksa stojący za podjęciem tej dyskusji. Jak stwierdził w Teoriach wartości dodatkowej: „wyodrębnienie pracy produkcyjnej od innych rodzajów pracy ma jednakże szczególnie ważkie znaczenie, gdyż ono właśnie wyraża tę określoną postać pracy, na której opiera się cały kapitalistyczny sposób produkcji i kapitał” (Marks 1959, 416). Konkretniej całokształt stosunków społecznych, w których znajduje się dana czynność i jej podmiot wytwarzający wartość dodatkową dla kapitału robotnik. Gdy hegemoniczna postać wydobywania wartości dodatkowej z pracy ulega przemianie (np. w skutek postulowanego przez postoperaistów „stawania się renty zyskiem”, zob. Vercellone 2010), a tym samym zmieni się stosunek zachodzący między praca a kapitałem, przekształceniu ulegaja również formy narzucania produkcyjności pracy.

Właśnie w tym Marksowskim podejściu do pracy produkcyjnej/nieprodukcyjnej, zakładającym, z jednej strony, że ta para pojęciowa jest kluczowa dla zrozumienia rzeczywiście funkcjonującego kapitalistycznego sposobu produkcji, z drugiej zaś, że zasięg jej funkcjonowania jest nieustannie wyznaczany w ramach stosunku sił między klasami, chciałbym osadzić dalsze rozważania składające się na ten tekst. Zanim do tego dojdzie, prześledźmy jeszcze stosunek Marksa do pracy i produkcji interesującego nas sektora wytwarzania i transmisji wiedzy. 


\subsection{Marksowskie przykłady pracy produkcyjnej w sferze produkcji niematerialnej}

Pomimo czytelności powyżej zarysowanych argumentów niektórzy marksiści uparcie obstawali przy jednoznacznym określaniu treści czy charakteru pracy produkcyjnej. Ernst Mandel, dla przykładu, uważał, że produkcyjna w Marksowskim sensie jest wyłącznie wymiana między człowiekiem a natura, w związku z czym produkcyjną może być wyłącznie praca materialna. Co więcej, jeszcze w latach siedemdziesiątych dwudziestego wieku z obserwacji zaniku tego rodzaju pracy na Zachodzie (w skutek rozrostu sektora usług i stopniowej relokacji przemysłu w inne regiony globu) wyciagał wniosek, że jest to ogólna zapowiedź nadciagającego upadku kapitalizmu (Mandel 1978, 377-407). Wyjaśniliśmy już powyżej, że tego rodzaju odczytania nie tylko nie sa zgodne z podstawowymi założeniami Marksowskiej metody (przede wszystkim analizy stosunków społecznych), ale również z wyrażanymi wprost uwagami rozsianymi w różnych częściach jego dzieła (których Mandel nie mógł przecież nie znać). Trudno wyjaśnić tego rodzaju dogmatycznie zaślepione postawy, które wciąż jeszcze pokutuja u części najbardziej twardogłowych polskich marksistów.

By przeciąć tego rodzaju naiwną argumentację, choć przykłady można by mnożyć, w poniższym fragmencie ograniczę się jedynie do przytoczenia tych Marksowskich odniesień do postaci pracy niematerialnej, które moga nam pomóc w zrozumieniu współczesnego narzucania produkcyjności pracy akademickiej w interesującym nas aspekcie (publikowania wyników badawczych).

Słynne porównanie nauczyciela w prywatnej i nastawionej na generowanie zysków szkole do pracownika fabryki kiełbasy z Kapitału zostało rozwinięte we fragmencie Rezultatów. Co istotne, Marks wchodzi tu na chwilę, na interesujący nas obszar: „Belfer uczący innych nie jest żadnym produkcyjnym robotnikiem. Ale belfer, który dostał z innymi angaż jako pracownik najemny w jakimś instytucie, by swoją praca pomnażać pieniądze entrepreneura tej knowledge montering institution, jest robotnikiem produkcyjnym" (Marks 2013, 119). Dla Marksa nie liczy się zatem treść pracy, ale sama forma pracy najemnej, którą objęty zostaje nauczyciel, jak również fakt, że instytucja, w której pracuje jest nastawiona na generowanie wartości dodatkowej w postaci zysku - spieniężenie wytwarzanej i przekazywanej przez niego wiedzy. To samo tyczy się sytuacji, gdy pracownik naukowy („literacki proletariusz”) tworzy dzieła dla swojego wydawcy. Zdaniem Marksa: „pisarz, który dostarcza fabryczną pracę swojemu księgarzowi, jest robotnikiem produkcyjnym.” [...],,literacki proletariusz z Lipska, który na rozkaz swojego księgarza produkuje książki, np. kompendia o ekonomii politycznej, jest dużo bliższy produkcyjnemu robotnikowi, o ile jego produkcja subsumowana jest pod kapitał i zachodzi jedynie w celu pomnożenia jego wartości." (2013, 119). Zwróćmy uwagę na ten ostatni fragment - literacki proletariusz zbliża się tu do robotnika produkcyjnego (nie osiaga tego stanu w pełni), gdy jego wytwory zmieniane są przez księgarza/wydawcę w towar i służą pomnożeniu jego kapitału. Przekazanie dzieł (i praw do ich wydania oraz czerpania z nich 
zysków) kapitalistycznemu wydawcy jest dla Marksa formą zawiązania się stosunku mieszanej/hybrydycznej subsumcji właściwej temu, co w innym miejscu Marks określi mianem formy przejściowej produkcji (Marks 2015, por. Szadkowski 2015, 195-197). Proces produkcji książki naukowej (jako całość) może być subsumowany pod kapitał, tym samym autor jako część składowa robotnika łącznego takiej produkcji stać się może pracownikiem produkcyjnym.

Dlaczego wobec tego Marks nie zajął się tymi obszarami kapitalistycznej produkcji i nie zintegrował ich specyfiki ze swoja wykładnią teorii wartości oraz wizja produkcji w gospodarce, w której panuje kapitalistyczny sposób produkcji? Wyjaśnia to w Rezultatach pisząc, że: „większość tych rodzajów pracy, rozpatrywanych według swojej formy, nie jest w zasadzie podporządkowana formalnie pod kapitał. Należą one raczej do form przejściowych" (Marks 2013, 119). Gdzie indziej dodaje jeszcze (odnosząc się również do produkcyjnej pracy niematerialnej), że: „Wszystkie te przejawy produkcji kapitalistycznej w omawianych dziedzinach są tak nieistotne w porównaniu z całością produkcji, że można ich zupełnie nie uwzględniać” (Marks 1959, 432). Marks „pomija” zatem powyżej dyskutowane obszary, traktując je jako w zasadzie nieistotne. Z punktu widzenia dziewiętnastowiecznej produkcji miał w tym zapewne rację. Jak jednak pokazaliśmy we wprowadzeniu tego artykułu, dziś kapitalistyczny przemysł wydawnictw akademickich stanowi istotny, ciągle rosnacy obszar i należy przyjrzeć się sposobom, w jakie czerpie korzyści z pracy akademickiej.

\section{Dwustronna perspektywa na pracę produkcyjną i nieprodukcyjną}

W istotę ekonomii politycznej wpisana jest zasadnicza dwoistość, na którą ponad sto lat temu wskazywała przenikliwie Róża Luksemburg (1959). Jak pisała: „przy podstawowym pytaniu, co to jest w istocie rzeczy ekonomia polityczna i co stanowi jej podstawowe zagadnienie, rozchodzą się dziś drogi poznania burżuazyjnego i proletariackiego" (1959, 72). Podczas gdy pierwsza dziedzina poznania wykorzystuje siatkę swoich kategorii do skrycia anarchii kapitalistycznej produkcji, druga posługuje się nią w celu jej obnażenia, by ostatecznie na jej zgliszczach zbudować system umożliwiający realizację stale wzrastających potrzeb klasy robotniczej. Te dwie perspektywy, choć nakładają się na siebie w obszarze analizy kapitalistycznych stosunków (jedna niejako nadbudowuje się nad osiąnięciami drugiej), są ze sobą niewspółmierne, a ostatecznie - antagonistyczne.

Nie inaczej jest $\mathrm{z}$ podstawowymi kategoriami ekonomii politycznej, w tym $z$ interesująca nas tutaj para pojęciowa pracy produkcyjnej i nieprodukcyjnej. Jak pisze Marks: „Tylko burżuazyjna buta, która kapitalistyczną formę produkcji uznaje za jej formę absolutna, a tym samym za naturalną formę produkcji, może pomylić pytanie, czym są praca produkcyjna i produkcyjny robotnik z punktu widzenia kapitału, z pytaniem czym w ogóle jest praca 
produkcyjna" (2013, 112). Naturalizacja kapitalistycznej rzeczywistości, idąca w parze z absolutyzacją kategorii służących do jej opisu, jest nie tylko czymś bezwzględnie atakowanym przez Marksa (por. 1986, 39-61), ale również zawsze świadomie podejmowanym, gdy przychodzi mu przeszczepiać te kategorie do własnego wywodu. Kilkukrotnie zatem wskazuje on na to rozszczepienie, jak na przykład w Teoriach wartości dodatkowej, gdzie rzeczywista produkcyjność pracy wiąże z koniecznościa zniesienia fundamentów wytwarzania wartości dodatkowej i przekazaniem stwarzanej nadwyżki w ręce robotników. Marks pisze: „Przypuśćmy jednak, że kapitał w ogóle nie istnieje, lecz że robotnik sam przywłaszcza sobie pracę dodatkowa, czyli nadwyżkę wartości, które wyprodukował, ponad wartości, które spożył. Tylko wtedy można o tej pracy powiedzieć, że jest naprawdę produkcyjna, tzn. że tworzy nowe wartości” (Marks 1959, 146). W przywołanych fragmentach uwidacznia się zatem nie tylko ontologicznie neutralny charakter pracy („pracy w ogóle”), ale również możliwość istnienia przynajmniej dwóch, przeciwstawnych sobie, trybów produkcyjności: produkcyjności dla kapitału i produkcyjności dla robotnika.

Ta dwoistość jest punktem wyjścia dla formułowania współczesnych ujęć produkcyjności i nieprodukcyjności pracy. Za dobry przykład może posłużyć David Harvie (2005), według którego to rozróżnienie musi być traktowane jako kategoria walki, a nie jako kategoria ruchu kapitału. W walce bowiem ma ono swój początek. Kapitał nieustannie dąży do uczynienia każdej aktywności praca produkcyjna. Odwrotnie, klasa robotnicza powinna dażyć do uczynienia jak największej ilości aktywności pracą nieprodukcyjną (dla kapitału). Według Harviego walka przeciwko przejawom działania prawa wartości, przeciwko narzucaniu społecznej miary coraz to nowym obszarom ludzkiej (i nie-ludzkiej) aktywności jest istotą walki przeciwko pracy produkcyjnej (Harvie 2005, 30). Procesy samorozwoju klasy robotniczej są nieprodukcyjne z perspektywy kapitału, a jednak to one stanowią oś budowy komunistycznego społeczeństwa przyszłości.

Tego rodzaju wizja rozwijana jest również m.in. przez Michaela Lebowitza (2003) czy Antonia Negriego (2014). Lebowitz w Beyond Capital. The Political Economy of the Working Class dokonał skutecznej próby filologicznego opracowania koncepcji „dwustronnego marksizmu”, wskazując jednocześnie, że opracowane przez Marksa, za Smithem, pojęcie pracy produkcyjnej ujęte jest właśnie jednostronnie - z perspektywy kapitału. Wspierający się na nim jednostronny marksizm jest nie tylko wystawiony na łatwą krytykę, ale równiė̇ nie stanowi żadnego wyzwania dla kapitału. Praca produkcyjna dla robotnika to praca wytwarzająca wartości użytkowe dla robotników, praca reprodukcyjna, aktywności rozwijające i sprzyjające rozwojowi istot ludzkich. Praca produkcyjną w tym sensie jest zatem wyłącznie to, co buntuje się przeciw wyzyskowi w ruchu samopomnażania się robotniczej pracy społecznej - zbiorowej sile wytwarzającej to, co wspólne. 
Jak już stwierdziliśmy, Marks m.in. w Zarysie wskazuje na nieadekwatność pojęcia pracy bezpośredniej dla zdefiniowania pracy produkcyjnej na określonym stadium rozwoju produkcji kapitalistycznej i rozwijanej przez nią kooperacji na skalę społeczna. Stanowi to również punkt wyjścia dla dokonywanego przez Negriego rozwinięcia koncepcji pracy prawdziwie produkcyjnej jako władzy konstytuującej. Choć włoski marksista stwierdza, że to w Kapitale „pojęcie pracy produkcyjnej bezpośredniej zostaje ostatecznie wpisane w pojęcie społecznej pracy produkcyjnej” (Negri 2014, 205), to jego głównym punktem odniesienia jest wizja naszkicowana przez Marksa w tzw. „Fragmencie o maszynach” (wchodzącym w skład Grundrisse, zob. Marks 1986; por. Szadkowski 2013), gdzie w ogólną dynamikę rozwoju technologicznego w kapitalizmie i znaczeniu, jakie ma dla niego produkcja naukowa, wpisana została konfliktowa relacja między czasem pochłanianym przez produkcję a czasem do dyspozycji robotnika. Osią, na której rozgrywa się ten konflikt jest stopniowo malejący udział bezpośredniej pracy w wytwarzaniu wartości przeciwstawiony rosnącemu znaczeniu produkcyjności całokształtu stosunków społecznych:

\begin{abstract}
W miarę jak kapitał wprowadza czas pracy - po prostu ilość pracy - jako jedyny element określający wartość, praca bezpośrednia i jej ilość przestają stanowić określająca zasadę produkcji: tworzenie wartości użytkowych; praca bezpośrednia zostaje ilościowo zepchnięta do niewielkiego udziału, a jakościowo sprowadzona do momentu wprawdzie niezbędnego, lecz podrzędnego w porównaniu z powszechną pracą naukowa, ze stosowaniem nauk przyrodniczych w technice z jednej strony, a z ogólną siłą wytwórczą zrodzona ze społecznej struktury całokształtu produkcji, występująca jako przyrodzony dar pracy społecznej (chociaż jest wytworem historii) z drugiej (Marks 1986, 568-569).
\end{abstract}

Tendencja do zwiększania naszych kolektywnych sił i zasobów pozwalających na cieszenie się ich efektami w warunkach społecznej harmonii jest niejako wpisana w dynamikę rozwoju kapitalistycznego. Samo załamanie podstawy miary (bezpośredniej pracy mierzonej czasem) nie stanowi jednak automatycznie otwartej furtki do nowego układu sił w kapitalistycznej gospodarce - nie pociaga za sobą jej krachu. Inaczej niż Negri uważam, że kapitał świetnie sobie radzi z wynajdywaniem miary dla tej pracy społecznej (czego interesująca nas w tym tekście praca akademicka jest świetnym przykładem), wraz z rozwojem zaobserwowanego przez Marksa procesu rośnie jednak społecznie odczuwana skala irracjonalności przykładania tych miar do społecznej rzeczywistości produkcji.

Nie zmienia to jednak faktu, że Negri trafnie określił charakter pracy produkcyjnej w nowych warunkach: ,jako całokształt wyzyskiwanej pracy społecznej przeciwstawiającej się (i obiektywnie antagonistycznej wobec) [...] rozmaitym formom, w których kapitalizm podtrzymuje swe panowanie. Pracę produkcyjną wówczas, w odróżnieniu od władzy kapitalistycznej, będzie można ująć jako tę zbiorową siłę, która wytwarza dobro wspólne" 
(Negri 2014, 223). Wyzysk w tym kontekście coraz częściej przybierać ma „postać wywłaszczenia społecznej kooperacji, zafałszowania tego, co wspólne” (2014, 223).

W dalszej części tego tekstu zakładam, że w kategorie tego, co produkcyjne/ nieprodukcyjne w warunkach produkcji kapitalistycznej wpisane jest antagonistyczne napięcie. Należy stwierdzić, że istniejąca uprzednio produkcyjność danej aktywności dla wykonującej ją grupy jest nie tylko punktem wyjścia dla sprawnie działającej produkcyjności pracy dla kapitału, ale również, że materialny ruch stojący u podstaw kapitalistycznego rozwoju stwarza warunki dla rozwinięcia się społecznej produkcji na niespotykaną dotąd skalę, którą podkopuje właściwe kapitałowi narzucanie nieodpowiadające jej heterogeniczności i bogactwu miary. Inaczej niż Negri czy Harvie dostrzegam jednak istotność zrozumienia współczesnych mechanizmów, w oparciu o które kapitał dąży do nieustannego narzucania produkcyjności temu, co żywe. Jeśli kapitał nieustannie dąży do przekształcenia i podporządkowania sobie wszelkiego rodzaju aktywności jako aktywności produkcyjnych - musimy być świadomi prawidłowości tego ruchu i brać je pod uwage przy formułowaniu naszych strategii oporu. Dwustronna perspektywa na pracę produkcyjną i nieprodukcyjną byłaby wobec tego zgodna z istotą proletariackiej nauki krytyki ekonomii politycznej - ujmującej jednocześnie kapitał w jego ograniczeniach, jak i wskazującej warunki dla zaistnienia autonomicznej wspólnoty wytwórców.

\section{Bezpośrednio produkcyjna praca akademicka}

Nie ma jednego podejścia do produkcyjnego aspektu pracy akademickiej, szczególnie w jej aspekcie związanym z prowadzeniem badań i ich efektami. Benoit Godin (2009) dostarczył bardzo pożytecznej historycznej klasyfikacji zmieniającego się głównonurtowego podejścia do produkcyjności nauki, które od dziewiętnastego wieku po dzień dzisiejszy opierało się przede wszystkim na kategoriach statystycznych. Wyróżnił zatem: a) produkcyjność jako reprodukcje (danej wspólnoty badaczy); b) produkcyjność jako wydajność (liczbę powszechnie cytowanych publikacji wysokiej jakości) w klasycznym bibliometrycznym sensie; c) produkcyjność jako skuteczność (w znaczeniu wskaźników stopy zwrotu z publicznych inwestycji w naukę); d) produkcyjność jako rezultat (wpływ nauki na produkcyjność ekonomiczna) (Godin 2009, 549). Wszystkich z tych znaczeń możemy dopatrzeć się w dzisiejszych sposobach rozumienia produkcyjności nauki wykorzystywanych w reformach systemów szkolnictwa wyższego i nauki przez rządy czy międzynarodowe ciała doradzające w zakresie kierunków tych reform. Żadne jednak nie ujmuje w sposób bezpośredni interesującego nas związku między pracą akademicką a kapitałem.

W tym celu należy sięgnąć po marksistowskie interpretacje produkcyjności pracy w tym obszarze. Przytaczany już wcześniej, David Harvie uważa, że rozróżnienie na pracę 
produkcyjną i nieprodukcyjną w społeczeństwie kapitalistycznym determinowane jest przez aktualny układ sił w ramach antagonizmu klasowego. Każda aktywność ma potencjał do stania się zarówno produkcyjną, jak i nieprodukcyjną dla kapitału. Szalę przeważa zawsze walka klasowa. Według niego obecnie mamy jednak do czynienia z podporządkowaniem sektora edukacji (wyższej) kapitałowi, a w związku z tym, praca w nim ma przede wszystkim charakter produkcyjny (Harvie 2005). Podporządkowanie to dotyczy różnego rodzaju miar i wskaźników odwzorowujących logikę działania prawa wartości w tym sektorze (De Angelis i Harvie 2009). Simon Marginson ukazal podobne napięcia w Marksowskim zastosowaniu pojęcia pracy produkcyjnej, wskazując, że kapitał osiąga produkcyjność sektora usług edukacyjnych, poddając prywatyzacji i kapitalizacji publiczne instytucje szkolnictwa wyższego (Marginson 1998). Podobnie uważają Bruno Gulli (2009) czy Stefano Harney i Fred Moten (1998), uznając sektor uniwersytecki za ostatnią twierdzę opierającą się (choć coraz słabiej) postępującemu pochodowi realnej subsumcji - wraz z nia praca akademicka przekształcana jest w pracę produkcyjną dla kapitału. $\mathrm{Na}$ ten sam fakt w swoich analizach sektora przemysłowego zwraca uwagę Harry Bravermann twierdząc, że granice tego, co produkcyjne nieustannie się rozszerzaja, w związku z czym wciąż pojawiaja się nowe przemysły (sektory) oraz towary (Bravermann 1998, 284-294). Wszystkie te stanowiska łączy przekonanie o niejako uniwersalizującej sile kapitału rozciagającego swoje stosunki na nowe obszary, niezależnie od ich pierwotnej specyfiki. Nawet jeśli praktyce subsumcji pracy pod kapitał towarzyszy zaciekły opór, pierwotna specyfika podporządkowywanego sektora z założenia nie wpływa na odkształcanie sposobu funkcjonowania w nim kapitału.

Inaczej sprawa wygląda ze znaczną częścią obszarów produkcji niematerialnej, w szczególności z nauką i szkolnictwem wyższym. Warunki, o których pisze Marks, tzn. włączenie pracy akademickiej w obręb prywatnego i nastawionego na zysk przedsiębiorstwa (na modłę wspomnianego już prywatnego instytutu czy „fabryki kiełbasy”), zatrudniającego kadrę w oparciu o stosunek pracy najemnej i oferującego towar, którego wymiana na rynku realizuje wartość dodatkowa, zachodzą w ramach tego sektora stosunkowo rzadko. Trzon systemów szkolnictwa wyższego i nauki stanowia instytucje publiczne lub prywatne nienastawione na zysk. Ten fakt zwrócił niedawno uwagę Marginsona (2015) gdy starał się on odpowiedzieć na pytanie, dlaczego lata wdrażania neoliberalnego modelu reform szkolnictwa wyższego i nauki w paradygmacie Nowego Zarządzania Publicznego nie przyniosły zakładanych efektów. Przede wszystkim zaś, dlaczego nie doprowadziły do stworzenia prawdziwie kapitalistycznych rynków w tym obszarze. Przy tej okazji nie tylko precyzyjnie opisał ich anatomię, ale również celnie wypunktował ograniczenia. Położył istotny nacisk na wewnetrzne (charakter wiedzy jako dobra publicznego i niezbywalną konkurencję statusowa w polu akademickim) i zewnetrzne (przede wszystkim polityczne, związane ze znaczeniem jakie szkolnictwo wyższe ma dla państw narodowych) ograniczenia wynikające ze specyfiki sektora, 
które uniemożliwiają realizacje kapitalistycznych rynków poza wąskimi wyspami ściśle nastawionej na zysk produkcji.

Problemem z tym podejściem polega jednak na tym, że ignoruje ono wszystkie kwestie związane z kapitalistycznymi aspektami funkcjonowania dzisiejszych systemów szkolnictwa wyższego, w tym w szczególności kapitalistycznej produkcji odbywającej się w jego ramach. Pouczający jest jednak sposób, w jaki Marginson polemizuje z marksistowskimi odczytaniami współczesnych przemian w szkolnictwie wyższym. Jego wyobrażony przeciwnik z kształtu przypomina przedstawiciela marksistowskiego redukcjonizmu ekonomicznego czy wręcz stalinowskiego wulgarnego materialistę dialektycznego, którego jedynym narzędziem analizy jest model bazy i nadbudowy, w którym szkolnictwo wyższe i nauka mieszczą się albo w jednym (uniwersytet-fabryka), albo drugim członie (ideologiczny aparat państwa). W ten sposób zatarciu miałaby ulegać unikalna specyfika pracy akademickiej i jej wytworów. Samo zrozumienie mechanizmu, w jaki kapitał podporządkowuje pracę akademicką na poziomie całych systemów szkolnictwa wyższego, wykorzystując w tym celu np. mechanizmy konkurencji o status w nauce leży niestety poza zasięgiem aparatu analitycznego, jak również wglądu empirycznego rozwijanego przez Marginsona. Choć należy przyznać, że propozycje upatrujące w dzisiejszym uniwersytecie fordowskiej fabryki łatwo podkładaja się pod taką krytykę, to jednak nie sposób zawęzić do nich całego spektrum marksistowskich analiz szkolnictwa wyższego.

By umknąć ograniczeniom zarysowanych powyżej perspektyw należałoby, idąc śladem Marksa, a za nim Negriego (2014), wkroczyć na teren systemowo/społecznie rozumianej produkcyjności pracy akademickiej. Krok ten zostanie postawiony w następnej części artykułu.

\section{Systemowa produkcyjność pracy akademickiej}

Zadaniem stojącym przed analizą marksistowska, która chciałaby wyjść z propozycją precyzyjnego ujmowania dwoistej produkcyjności pracy akademickiej, jest wskazanie w jaki sposób logika praktyk właściwych dla danego pola (pola akademickiego) zostaje wpierw zinstrumentalizowana (hybrydyczna subsumcja), wchłonięta (formalna subsumcja), a następnie przetworzona (realna subsumcja) przez kapitał (por. Szadkowski 2015, 174-223; Marks 2015), tworząc warunki do jej przekroczenia. Kluczem do tego przedsięwzięcia jest zbadanie napięcia zachodzącego między indywidualizującą i wyabstrahowującą miarą rozwijaną i narzucaną pracy przez kapitał a społeczna podstawą akademickiej produkcji (i samej miary).

Kilkukrotnie wspominaliśmy już w tym tekście o mierze - wypadałoby wyjaśnić jakie ma ona znaczenie dla interesującego nas zjawiska. Wartość to społecznie niezbędny czas pracy (Harvey 2010), ten zaś stanowi umocowaną w kapitalistycznej produkcji miarę, pod którą 
podciagane są wszystkie procesy pracy. „Miara” i dążenie do abstrahowania są nieodłącznymi elementami kapitalistycznej rzeczywistości, a globalny system szkolnictwa wyższego stał się obszarem, w którym kapitał lokuje dziś i umacnia dzięki nim swoje procesy pomnażania wartości i ekstrakcji wartości dodatkowej. Żeby na trwałe ufundować swoje panowanie nad określonym obszarem oraz określić zachodzące w nim aktywności jako produkcyjne, kapitał musi zainstalować w nich procesy pomiaru, które będą napędzały jego ruch. Kapitalistyczna miara w szkolnictwie wyższym i nauce jest odwzorowaniem stosunków społecznych zawiązywanych w nich przez pracę akademicka, jest, jak chciałby przytoczony już powyżej Negri, narzędziem „wywłaszczenia społecznej kooperacji, zafałszowania tego, co wspólne” (2014, 223). W kolejnych krokach spróbuję nadać tym ogólnym stwierdzeniom trochę konkretności.

$\mathrm{Na}$ systemowy sposób funkcjonowania i kluczową kwestię miary w relacjach między pracą akademicka a kapitałem wskazuja w swoim tekście o brytyjskim systemie De Angelis i Harvie. W szkolnictwie wyższym walka o narzucanie pomiaru działa poprzez dwa równoległe procesy (De Angelis i Harvie 2009, 26). Z jednej strony odbywa się ruch diachroniczny, presja na obniżanie społecznie niezbędnego czasu pracy dla „produkcji” idei i afektów w ramach zarówno badania, jak i kształcenia. Kontekst dla tego ruchu stanowi polityka ciąłych oszczędności i kurczenie się publicznych budżetów nauki i szkolnictwa wyższego. W tym diachronicznym procesie po prostu wyciska się więcej z pracy akademickiej - więcej tekstów, więcej godzin spędzonych ze studentami, więcej patentów etc. Z drugiej strony, na poziomie ogólnokrajowym i globalnym (ten wymiar umknął uwadze autorów) zachodzi ruch synchroniczny, ruch ciagłego porównywania i zliczania aktywności pracy akademickiej, w ramach którego heterogeniczne czynności podciagnięte zostają pod wspólną miarę przydającąim charakter pracy abstrakcyjnej. W przypadku pracy badawczej miarą, przy pomocy której podciąga się dokonania na różnorodnych frontach nauki pod wspólny mianownik są np. wskaźniki bibliometryczne w rodzaju wskaźnika Journal Impact Factor przekładanego na wartość osiagnięć poszczególnych badaczy w procesach ewaluacji. W ten sposób tworzona jest podstawa dla funkcjonowania mechanizmów szacujących niezbędny czas pracy wykonywanej w sektorze. Oba te procesy sa powiazzane i wzmacniają się nawzajem. Nieustanna walka kapitału, aby narzucić „prawo wartości”, jest jednoczesną walką o narzucenie miary stanowiącej podstawowy mechanizm ugruntowujący produkcyjność pracy.

De Angelis i Harvie w swojej dyskusji nad procedurami ewaluacji pracy w dużej mierze publicznym systemie brytyjskim nie są w stanie wykazać bezpośredniego powiązania między praktyka pomiaru a funkcjonującym w tym polu kapitałem. Naświetlenie samej procedury pomiaru pracy wystarcza im do stwierdzenia, że mamy do czynienia z narzucaniem prawa wartości, a tym samym z wykonywaniem pracy produkcyjnej dla kapitału. Ten ostatni pozostaje jednak w tej analizie nieuchwytny. Carlo Vercellone (2007) słusznie wskazuje na nieustanne 
dążenie kapitału do uniknięcia konieczności nieruchomienia w procesie produkcji. Na każdym etapie swojego rozwoju kapitał musi decydować o stopniu zaangażowania w obszar produkcji. W niej bowiem musi zawsze zastygać na pewien okres w bezruchu, co sprzeczne jest z jego istota. Zaangażowanie w organizację i kontrolę przedsięwzięcia naukowego jest dodatkowo obciążone na tyle istotnym ryzykiem niepowodzenia uzyskania szybkiego czy nawet długoterminowego zysku (Mazzucato 2013), że trudno sobie wyobrazić istnienie na masową skalę prywatnych instytutów, o których pisał Marks - szczególnie w obszarze badań podstawowych. Jednakże kapitał zaprzęga różnego rodzaju mechanizmy w celu umożliwienia własnych procesów waloryzacji również w tym obszarze. Przyjrzymy się im poniżej.

$\mathrm{Na}$ samym początku tego tekstu pisaliśmy o węźle problemowym leżącym u podstaw relacji między pracą a kapitałem w szkolnictwie wyższym i nauce. Splecione są w nim właściwe wspólnocie naukowej mechanizmy dystrybucji prestiżu, krajowe i transnarodowe procedury ewaluacji pracy naukowej prowadzące do zaostrzania się konkurencji między badaczami, instytucjami i systemami oraz dynamicznie rozwijający się przemysł wydawniczy, którego wsparciem są firmy dostarczające wskaźników i metryk umożliwiających tworzenie rankingów czasopism, a następnie uniwersytetów i badaczy. Rozwiązanie tego węzła jest sposobem na dookreślenie dwoistej produkcyjności pracy akademickiej. W tym właśnie celu wykorzystamy ustalenia postoperaistów.

Podstawowym spostrzeżeniem, od którego należy rozpocząć jest uwaga Gigiego Roggero dotycząca tego, że w kapitalizmie kognitywnym „kapitał jest coraz mniej zdolny do organizacji »odgórnego« cyklu kooperacji” $(2011,71)$. Z racji tego, że nie jest dłużej zdolny do realizacji tego zadania, przestaje być tė̇ w istocie, zwłaszcza w tych najbardziej opartych na współdziałaniu sektorach, do których możemy z pewnością zaliczyć naukę, w ogóle zainteresowany przejmowaniem kontroli nad procesem produkcji. Jeśli przyjrzymy się w tym miejscu krajobrazowi globalnego szkolnictwa wyższego, zobaczymy, że z perspektywy kapitału istotne jest to, co samo wchodzi w ustanawiane ramy pomiaru, wyłącznie to, co jest widzialne i zliczalne, cała zaś reszta procesów może być swobodnie podtrzymywana i zasilana przez rządy i państwa. Mam przez to na myśli m.in. publikacje w „najlepszym obiegu” czasopism czy patenty. W realiach szkolnictwa wyższego kapitał przeprowadza procesy pomnażania wartości nie tyle poprzez panowanie nad pojedynczą instytucja, co wyznaczanie warunków funkcjonowania dla całego globalnego systemu instytucji z ich bardziej liczącymi się (pod względem wydajności produkcyjnej) centrami oraz mniej liczącymi się (ale ważnymi jeśli chodzi o konsumpcję) peryferiami systemu. Instytucje z marginesów globalnego systemu szkolnictwa wyższego, niezdolne ani do produkcji, ani do dostatecznej konsumpcji oferowanych przez kapitał wydawniczy towarów, nie mają w tej grze żadnego znaczenia. Jak pisze Roggero, ,akt akumulacji, przechwytywanie wartości produkowanej wspólnie przez żywą pracę/wiedzę, ma coraz częściej miejsce na końcu cyklu" $(2011,71)$. Podobnie dzieje się w relacji między cyklem 
produkcji opłacanych z publicznych pieniędzy badań a efektem publikacyjnym przechwytywanym przez wydawniczy kapitał handlowy. Ciężko właściwie wyobrazić sobie bardziej krańcowe położenie kapitału w procesie produkcji wiedzy naukowej niż położenie w miejscu deponowania wyników prowadzonych badań. Trudno też znaleźć przykład lepiej odpowiadający postoperaistycznym tezom o tym, że aktywność żywej pracy/żywej wiedzy zawsze przekracza ramy pomiaru nieustannie narzucane jej przez kapitał (Celis 2015) niż obszar produkcji naukowej.

Głównym dążeniem kapitału w tej sferze jest zatem czynienie niezwykle heterogenicznych wytworów ludzkiego umysłu zliczalnymi i porównywalnymi. Z jednej strony, zachodzące w szkolnictwie wyższym praktyki pomiaru wydobywają wartość z opisywanych przez nie stosunków; z drugiej strony wskazuja, co jest bezpośrednio produktywne dla kapitału. To miara staje się fundamentem decyzji o przyznaniu produkcyjnego/nieprodukcyjnego statusu pracy akademickiej. Możemy powiedzieć wręcz, jak chciałby Matteo Pasquinelli (2014a, 2014b), że kapitał jako taki jest zliczaniem czy miara - na pewno zaś nie jest w stanie obyć się bez miary. Interesujące nas firmy zajmujące się przetwarzaniem danych bibliometrycznych (jak Thomson Reuters czy Elsevier) stanowią centra kalkulacji na usługach kapitału wydawniczego, same, prowadzące działalność ściśle nastawioną na zysk, stanowią jedną z jego frakcji.

Pasquinelli, który od dłuższego czasu zajmuje się mechanizmami przekształcania wspólnego intelektu czy też intelektu powszechnego w sieciową wartość dodatkowa, w centrum swojej uwagi umieszcza różnego rodzaju algorytmy i mechanizmy generowania metadanych. W jednym ze swoich tekstów (Pasquinelli 2015) wyróżnia dwa rodzaje maszyn informacyjnych i algorytmów: a) umożliwiające przekład informacji na informację; b) umożliwiające akumulację informacji i wydobywanie metadanych tj. informacji o informacji. Mechanizmy wykorzystywane przez firmę Thomson Reuters w jej bazie Web of Science, a szczególnie jej flagowy produkt, Impact Factor, stanowia algorytm tego drugiego typu.

Jak pisze Pasquinelli, „Matadane są »miarąu informacji, wyliczeniem ich społecznego wymiaru i potencjalności ich przekształcenia w wartość” (Pasquinelli 2011, 153). Z trzech wymienianych przez niego aspektów funkcjonowania maszyn algorytmicznych wytwarzających i akumulujaccych metadane interesujący z naszej perspektywy jest ich pierwszy aspekt. Pasquinelli pisze bowiem, że „metadane używane są do pomiaru wartości stosunków społecznych. Na pierwszym poziomie akumulacja informacji odzwierciedla i mierzy produkcję stosunków społecznych w celu przekształcenia ich w wartość towarowa.” (2011, 154).

Mechanizmem, który może przybliżyć sposób funkcjonowania interesujących nas wskaźników i ich efektów dla pracy akademickiej jest Google PageRank, który według Pasquinellego stanowi diagram kapitalizmu kognitywnego. Sergey Brin oraz Lawrence Page w The Anatomy of a Large-Scale Hypertextual Web Search Engine, tekście, w którym w 1998 roku wyłożyli podstawy funkcjonowania algorytmu PageRank, zaznaczają, że jego podstawowa 
matryca logiczna zaczerpnięta została z mechanizmów zliczania cytowań ramach bibliometrii akademickiej - w pewnym sensie zatem praca akademicka i jej wewnętrzne mechanizmy szacowania wartości stanowią wzór dla dzisiejszych sposobów waluacji stosowanych przez kapitał. Google PageRank pozwala na wytwarzanie hierarchii wyników - w celu wyodrębnienia tych najbardziej trafnych. Jest zatem w stanie przekształcić zbiorową wiedzę (taką, jak ta wytwarzana przez system cytowań) we własnościową skalę wartości - w hierarchię, która sama w sobie przekształca się we własnościowy produkt. PageRank jest „maszyną przechwytu żywego czasu i żywej pracy zdolną do przekształcania wspólnego intelektu w sieciową wartość” (Pasquinelli 2009, 2). Podobny sposób określania wartości - jak wskazuje Pasquinelli - może zostać zastosowany w odniesieniu do jakiegokolwiek obiektu kognitywnego. „W przypadku zarówno publikacji akademickich, jak marek handlowych czy rankingów internetowych można założyć równoważne procesy kondensowania wartości” (2009, 5).

W ramach tego algorytmu: ,wartość określana jest zarówno przez ilość, jak i jakość przychodzących linków. W szczególności, link pochodzący z węzła o wysokiej randze posiada więcej wartości niż link pochodzący z węzła o niższej randze" (Pasquinelli 2009, 3). W przypadku baz indeksacyjnych w rodzaju Web of Science czy Scopus (to one licza się w większości dzisiejszych globalnych rankingów uniwersytetów) kwestia wartości węzła określana jest jako warunek progowy (sama możliwość znalezienia się na danej liście) - na liście indeksowane są czasopisma, które określane są (poprzez istniejące odniesienia do nich winnych „widzialnych” czasopismach) jako posiadające „wysoką range” - pozostałe, wykluczane są ze sfery widzialności. W ten sposób hierarchia samych odniesień jest trochę spłaszczana w samej bazie.

Należy jednak wbrew Pasquinellemu zaznaczyć, że w przypadku pracy akademickiej w relacji z wydawniczym kapitałem handlowym zapośredniczonej przez dostawców metadanych, nie tyle wytworzona wartość jest przechwytywana, ale miara pozwala ukazać się społecznemu i społecznie wytworzonemu heterogenicznemu bogactwu relacji (dobru wspólnemu) jako wartość. Mechanizmy przechwytu po prostu pozwalają ukierunkować (często przy pomocy instytucji państwowych - jak mamy do czynienia w przypadku państwowych procedur ewaluacji pracy naukowej, do których odnosili się m.in. De Angelis i Harvie 2009) społeczną heterogeniczną energię w celu wytwarzania tego, co może zostać zmierzone i ukazane jako wartość.

Algorytmy stojące za współczesnymi globalnymi rankingami uniwersytetów sa mechanizmami ustalania prestiżu w polu złożonym z instytucji szkolnictwa wyższego. Jednak zapośredniczenie dokonuje się na dwóch poziomach - rankingi są algorytmem drugiego stopnia - pierwszym są cytowania w określonych bazach. W ramach tych baz dokonuje się wpierw pozycjonowanie czasopism na podstawie aktywności pojedynczych badaczy (nie tylko ich wkładu pracy w postaci artykułów, ale również zastosowanych w nich odnośników 
bibliograficznych), następnie zaś dane i skonstruowane na ich podstawie wyniki porównań zasilają silniki rankingowych algorytmów. Parafrazując Pasquinellego można powiedzieć, że tym, co »impact factor« czy SNIF „rozpoznaje i mierzy jest wartość sieciowa w swojej postaci ilościowej" $(2009,6)$

O ile Google przy pomocy algorytmu PageRank uzyskało, jak pisze Pasquinelli, nie tylko „dominująca pozycję w magazynowaniu indeksów sieci, ale również monopol na produkowanie tej wartości sieciowej”, o tyle w polu produkcji naukowej i bibliometrii walka o sprawowanie monopolu toczy się między firmą Thomson Reuters z jej opatentowanym produktem Impact Factor oraz firmą Elsevier i różnorodnymi wskaźnikami wyliczanymi w oparciu o dane z bazy Scopus. Jednak o znaczeniu i sukcesie każdego z podmiotów świadczy ich pozycja w kontekście uwzględniania w globalnych rankingów szkolnictwa wyższego (tutaj zdecydowanie prym wiedzie firma Thomson Reuters) one bowiem skupiaja uwage ustawodawców, społeczeństw czy kierownictwa instytucji akademickich na całym świecie, przyczyniając się do zaostrzenia konkurencji między badaczami oraz instytucjami, a także do kanalizowania wyników publikacyjnych w czasopismach indeksowanych w tych bazach? ${ }^{7}$. W tych dwóch kontekstach (produkcji danych przekształcanych przez właścicieli baz w metadane zasilające globalne i krajowe porównania oraz publikowania wyników swych prac badawczych przede wszystkim w komercyjnych czasopismach zindeksowanych w tych bazach) należy dziś rozpatrywać produkcyjność pracy akademickiej dla kapitału.

\section{Podsumowanie - akademicka produkcja dobra wspólnego}

Dobrowolne poddawanie się stałemu wywłaszczeniu z efektów swojej pracy, które zachodzi w obszarze publikowania efektów badań przez pracę akademicką nosi znamiona trwałej relacji, jaka w zapośredniczeniu przez system miar zawiązuje z nią kapitał. W tym sensie można uznawać system, na który składają się wspierane działaniami krajowych rządów, sieci dostawców danych bibliometrycznych, komercyjnych wydawców czasopism i wreszcie twórców globalnych rankingów uniwersytetów, za złożony mechanizm subsumowania pracy akademickiej pod kapitał. Opisany powyżej, skomplikowany i rozciagnięty na cały globalny system nauki i szkolnictwa wyższego mechanizm pomiaru i porównywania pracy akademickiej umożliwia trwałe egzekwowanie kanalizowania wysiłków publikacyjnych w czasopismach należącej do małej grupy stale dokonujących ekspansji wydawców (Larivière i in. 2015). Jednocześnie stosowana w ramach tej relacji miara uwidacznia określoną przestrzeń wspólną między rozproszonymi po całym globie pracownikami i pracownicami akademickimi.

\footnotetext{
${ }^{7}$ A jak wskazałem w innym miejscu większość czasopism zindeksowanych na tych listach znajduje się w ręku kilku największych podmiotów wydawniczych (Szadkowski 2015, 163-169).
} 
Umożliwia przyspieszoną komunikację między badaczami, staje się fundamentem niedającego się przecenić w czasach hiperprodukcji naukowej, niedoskonałego systemu informacji zwrotnej o istotności publikowanych wyników. Wszystko to jednak w oparciu o istniejące uprzednio praktyki komunikacyjne wspólnoty naukowej ukierunkowane na produkcję wiedzy jako dobra wspólnego.

Widzieliśmy powyżej, wpierw na przykładzie protestu „The Cost of Knowledge” wymierzonego w firmę Elsevier, następnie w kontekście istotności procesów pomiaru i odpowiedzialnych za nie w skali globalnej dostawców metadanych, że nie tylko codzienne praktyki pracy akademickiej (cytowanie źródeł, recenzowanie artykułów itd.) stanowią podstawę wszystkich przedsięwzięć kapitału w polu nauki, ale również, że kapitał waloryzuje sieci relacji tworzonych w toku tej pracy przez akademików i przechwytuje tworzoną przez nie wartość. Cały proces komunikacji naukowej mógłby zatem odbywać się faktycznie kompletnie poza relacja z kapitałem - w immanentnej przestrzeni tworzenia tego, co wspólne. Mógłby choć dziś, prócz realnie istniejących, materialnych praktyk wspierających jego pasożytniczą akumulację, wiele na to nie wskazuje.

Pracownicy akademiccy nie przestają kolektywnie kwestionować tego stanu rzeczy. Przykładem są choćby The San Francisco Declaration on Research Assessment (DORA) czy opublikowany w czasopiśmie Nature Manifest Lejdejski (Hicks i in. 2015). Twardy sprzeciw wobec nadużywania wskaźników w rodzaju Impact Factor przy indywidualnej ocenie, a pośrednio, przeciwko wymuszaniu stale rosnącej produktywności i publikowania w określonych kanałach publikacyjnych należących do gigantów rynku wydawniczego, czy wreszcie postulat rozwinięcia alternatywnych sposobów oceny pracy akademickiej, wszystkie te działania wspierane przez tysiące naukowców i setki organizacji naukowych na całym świecie nie przyniosły dotąd trwałego efektu, ani nie skłoniły władz poszczególnych uniwersytetów czy ustawodawców do zrezygnowania z posługiwania się kapitalistyczną miara.

Prawdziwa produkcyjność pracy akademickiej, o której pisał Marks, tworzenie wiedzy bez zapośredniczania tego procesu w kapitale, wiedzy, która składałaby się na wspólne i wspólnie zarządzane bogactwo, wydaje się wymagać ostatecznego porzucenia miary lub też jakiejś formy jej istotnej modyfikacji. Jest to jednak kwestia do rozwinięcia w ramach osobnych rozważań. 


\section{Wykaz literatury}

Beverungen, Armin, Steffen Böhm i Christopher Land. 2012. „The Poverty of Journal Publishing." Organization 19(6): 929-938.

Blackmore, Paul, Kandiko, Camille B. 2011. „Motivation in academic life: a prestige economy." Research in Post-Compulsory Education 16(4): 399-411.

Bourdieu, Pierre. 1984. Homo Academicus. Tłum. Peter Collier. Stanford: Stanford University Press.

Böhm, Steffen i Land, Chris. 2009. „No measure for culture? Value in the new economy.” Capital \& Class 33(1): 75-98.

Braverman, Henry. 1998. Labor and Monopoly Capital. The Degradation of Work in the Twentieth Century. New York: Monthly Review Press.

Caffentzis, George. 2005. „Immeasurable Value? An Essay on Marx’s Legacy.” The Commoner 10: 87-114.

Cámara Izquierdo, Sergio. 2006. „, A value-oriented distinction between productive and unproductive labour." Capital \& Class 30(3): 37-63.

Celis, Claudio. 2015. , The Machinic Temporality of Metadata.” tripleC 13(1): 101-111.

Clark, William. 2006. Academic Charisma and the Origins of the Research University. Chicago: The University of Chicago Press.

De Angelis, Massimo. 2005. „Value(s), measure(s) and disciplinary markets'. The Commoner 10: 65-86.

De Angelis, Massimo i David Harvie. 2009. „„ „Cognitive Capitalism« and the Rat-Race: How Capital Measures Immaterial Labour in British Universities." Historical Materialism 17(3): 3-30.

De Solla Price, Derek. 1967. Mała nauka - Wielka nauka. Tłum. Piotr Graff. Warszawa: PWN.

Dill, David (2009). „Convergence and diversity. The role and influence of university rankings" W University Rankings, Diversity, and the New Landscape of Higher Education, red. Barbara Kehm, Bjorn Stensaker, Rotterdam: Sense Publishing.

Duménil, Gérard i Dominique Lévy. 2011. „Unproductive Labor as Profit-Rate-Maximizing Labor." Rethinking Marxism: A Journal of Economics, Culture \& Society 23(2): 216-225

Fuchs, Christian i Marisol Sandoval. 2013. „The Diamond Model of Open Access Publishing: Why Policy Makers, Scholars, Universities, Libraries, Labour Unions and the Publishing World Need to Take Non-Commercial, Non-Profit Open Access Serious." tripleC 13(2): 428-443.

Godin, Benoît. 2006. „On the Origins of Bibliometrics.” Scientometrics 68(1): 109-133.

Godin, Benoît. 2007. „From Eugenics to Scientometrics: Galton, Cattell, and Men of Science." Social Studies of Science 37(5): 691-728.

Godin, Benoit. 2009. „The Value of Science: Changing Conceptions of Scientific Productivity, 1869 to Circa 1970." Social Science Information 48(4): 547-586.

Gough, Ian. 1972. „Marx’s Theory of Productive and Unproductive Labour.” New Left Review 76: 47-72.

Gulli, Bruno. 2009. „Knowledge Production and the Superexploitation of Contingent Academic Labor." Workplace 16: 1-30. 
Gulli, Bruno. 2005. Labor of Fire. The Ontology of Labor between Economy and Culture. Temple Univerisity Press: Philadelphia.

Hardt, Michael i Antonio Negri. 2005. Imperium. Tłum. Adam Kołbaniuk, Sergiusz Ślusarski, Warszawa: W.A.B.

Hardt, Michael i Antonio Negri. 2012. Rzecz-pospolita. Poza wlasność prywatna i dobro publiczne. Tłum. Praktyka Teoretyczna. Kraków: Korporacja Ha-art.

Harney, Stefano i Fred Moten. 1998. „Doing academic work”. W Chalk Lines. The Politics of Work in the Managed University, red. Randy Martin, Durham: Duke University Press.

Harvey, David. 2010. A Companion to Marx's Capital. London: Verso.

Harvie, David. 2006. „Value production and struggle in the classroom: Teachers within, against and beyond capital." Capital \& Class 30(1): 1-32.

Harvie, David. 2005. „All labour produces value for capital and we all struggle against value.” The Commoner 10: 132-171.

Hazelkorn, Ellen. 2011. Rankings and the Reshaping of Higher Education. The Battle for World-Class Excellence. Basingstoke: Palgrave MacMillan.

Hicks, Diana, Paul Wouters, Ludo Waltman, Sarah de Rijcke i Ismael Rafols. 2015. „The Leiden Manifesto for research metrics". Nature, 22 April, 520: 429-431.

Houston, David. 1997. „Productive-Unproductive Labor: Rest in Peace.” Review of Radical Political Economics 29(1): 131-147.

Kehm, Barbara. 2013. „The impact of rankings on the European higher education landscape". W Global University Rankings. Challenges for European Higher Education, red. Tero Erkkila, Basingstoke: Palgrave MacMillan.

Kicillof, Axel i Guido Starosta. 2007. „Value form and class struggle: A critique of the autonomist theory of value" Capital \& Class 31(2): 13-40.

Laibman, David. 1999. „Productive and Unproductive Labor: A Comment.” Review of Radical Political Economics 31(2): 61-73

Larivière, Vincent, Stefanie Haustein i Philippe Mongeon. 2015. „The Oligopoly of Academic Publishers in the Digital Era." PLoS ONE 10(6): 1-15.

Lebowitz, Michael A. 2003. Beyond Capital. Political Economy of the Working Class. Basingstoke: Palgrave MacMillan.

Luksemburg, Róża. 1959. Wstęp do ekonomii politycznej. Warszawa: Książka i Wiedza.

Mandel, Ernst. 1978. Late Capitalism. London: Verso.

Marginson, Simon. 1998. „Value creation in the production of services. A note on Marx”. Cambridge Journal of Economics 22: 573-585.

Marginson, Simon. 2009. University Rankings and the Knowledge Economy. W Creativity and the Global Knowledge Economy, red. Michael A. Peters, Simon Marginson, Peter Murphy. Frankfurt am Main: Peter Lang.

Marginson, Simon. 2015. „O niemożliwości zaistnienia kapitalistycznych rynków w szkolnictwie wyższym”. Tłum. Krystian Szadkowski. Nauka i Szkolnictwo Wyższe 1(45): 11-37.

Marks, Karol. 1959. Teorie wartości dodatkowej, t. 1, Tłum. Czesław Grabowski, Felicja Romaniukowa, Władysław Sadowski. Warszawa: Książka i Wiedza. 
Marks, Karol. 1968. Kapitat. Krytyka ekonomii politycznej. Ksiega I: „Proces wytwarzania kapitalu”. Tłum. Paweł Hoffman, Bronisław Minc, Edward Lipiński. W Karol Marks, Fryderyk Engels. Drieła t. 23. Warszawa: Książka i Wiedza.

Marks, Karol. 1986. Zarys krytyki ekonomii politycznej. Tłum. Jan Wyrozembski Warszawa: Książka i Wiedza.

Marks, Karol. 2013. Kapitat 1.1. Rezultaty bezpośredniego procesu produkcji. Tłum. Mikołaj Ratajczak. Warszawa: Wydawnictwo Naukowe PWN.

Marks, Karol. 2015. „Formalna i realna subsumcja pracy pod kapitał. Formy przejściowe.” Tłum. Tomasz Płomiński, Mikołaj Ratajczak. Praktyka Teoretyczna 2(16): 125-148.

Mazzucato, Mariana. 2013. Entrepreneurial State: Debunking public vs. private sector myths. Anthem Books: London.

Meiksins, Peter. 1981. „Productive and Unproductive Labor and Marx's Theory of Class.” Review of Radical Political Economics 13: 32-42.

Mezzadra, Sandro i Brett Neilson. 2013. „Extraction, logistics, finance. Global crisis and the politics of operations." Radical Philosophy 178: 8-18.

Mohun, Simon. 2002. „Productive and unproductive labor: a reply to Houston and Laibman." Review of Radical Political Economics 34: 203-220.

Mohun, Simon. 1996. „Productive and Unproductive Labor in the Labor Theory of Value.” Review of Radical Political Economics 24 (4): 30-54.

Münch, Richard. 2013. „The colonization of the academic field by rankings. Restricting diversity and obstructing the progress of knowledge". W Global University Rankings. Challenges for European Higher Education, red. Tero Erkkila. Basingstoke: Palgrave MacMillan.

Münch, Richard. 2014. Academic Capitalism. Universities in the Global Struggle for Excellence. London: Routledge.

Neave, Guy. 2012. The Evaluative State, Institutional Autonomy and Re-engineering Higher Education in Western Europe. The Prince and His Pleasure. Basingstoke: Palgrave MacMillan.

Negri, Antonio. 2014. „Praca produkcyjna i nieprodukcyjna”. W LUM, Marks. Nowe perspektyny. Tłum. Sławomir Królak. Warszawa: Wydawnictwo Naukowe PWN.

Pasquinelli, Matteo. 2015. „Italian Operaismo and the Information Machine.” Theory, Culture \& Society 32(3): 49-68.

Pasquinelli, Matteo 2014a. „The Number of the Collective Beast: Value in the Age of the New Algorithmic Institutions of Ranking and Rating" http:// matteopasquinelli.com/number-of-the-collective-beast/

Pasquinelli, Matteo. 2014b. „The Labour of Abstraction: Seven Transitional Theses on Marxism and Accelerationism." Filip Magarine, no. 19. http:// fillip.ca/content/thelabour-of-abstraction

Pasquinelli, Matteo. 2009. „Google’s PageRank Algorithm: A Diagram of Cognitive Capitalism and the Rentier of the Common Intellect." W Deep Search, red. Konrad Becker, Filip Stalder London: Transaction Publishers.

Peekhaus, Wilhelm. 2012. „The Enclosure and Alienation of Academic Publishing: Lessons for the Professoriate." tripleC 10(2): 577-599.

Pitts, Frederick H. 2015. „Form-Giving Fire: Creative Industries as Marx’s ‘»Work of Combustion« and the Distinction Between Productive and Unproductive Labour". 
W Reconsidering Value and Labour in the Digital Age, red. Eran Fisher, Christian Fuchs. Basingstoke: Palgrave Macmillan.

Pitts, Frederick H. 2015. „Creative Industries, Value Theory, and Michael Heinrich’s New Reading of Marx". tripleC 13(1): 192-222.

Ratajczak, Mikołaj. 2015. „Divine Management of Worldly Matters: Agamben’s Theological Genealogy of Economy as a Political Philosophy of Praxis." Praktyka Teoretyczna 3(17): 75-105.

Roberts, Bruce. 2014. „Productive/Unproductive: Conceptual Topology.” Rethinking Marxism: A Journal of Economics, Culture \& Society, 26(3): 336-359.

Robinson, Bruce. 2014. „With a Different Marx: Value and the Contradictions of Web 2.0 Capitalism." The Information Society 31(1): 44-51.

Rubin, Isaak. 1990. Essays on Marx's Theory of Value. Tłum. Milos Samardzija, Fredy Perlman. Montreal: Black Rose Books.

Shore, Chris i Susan Wright. 2015. „Audit culture revisited. Rankings, ratings, and the reassembling of society". Current Anthropology 56(3): 421-444.

Storbeck, Olaf. 2012. „Teure Wissenschaft: Forscher boykottieren Fachverlag”. Handelsblatt https://www.handelsblatt.com/politik/konjunktur/oekonomie/nachrichten/teurewissenschaft-forscher-boykottieren-fachverlag/6203330.html

Savran, Sungur i Ahmet E. Tonak. 1999. „Productive and Unproductive Labour: An Attempt at Clarification and Classification." Capital \& Class 23(2): 113-52.

Szadkowski, Krystian. 2013. „Postoperaistyczne lektury Marksowskiego Fragmentu o maszynach w świetle krytyki”. Praktyka Teoretyczna 3(9): 63-110.

Szadkowski, Krystian. 2015. Uniwersytet jako dobro wspólne. Podstawy krytycznych badań nad szkolnictwem wy:szym. Warszawa: Wydawnictwo Naukowe PWN.

Thoburn, Nicholas. 2003. Deleuze, Marx and Politics. London: Routledge.

Vercellone, Carlo. 2007. „From Formal Subsumtion to General Intellect: Elements for a Marxist Reading of the Thesis of Cognitive Capitalism". Historical Materialism 15: 13-36.

Vercellone, Carlo. 2010. „The Crisis of the Law of Value and the Becoming-Rent of Profit”. W Crisis in the Global Economy. Financial Markets, Social Struggles and New Political Scenarios, red. Andrea Fumagalli, Sandro Mezzadra. Tłum. Jason Francis Mc Gimsey. Los Angeles: Semiotext(e).

Vostal, Flip. 2015. „Speed Kills, Speed Thrills: Constraining and Enabling Accelerations in Academic Work-life". Globalisation, Societies and Education 13(3): 295-314.

Ware, Mark i Michael Mabe. 2015. The STM Report: An Overview of Scientific and Scholarly Journal Publishing. The Hague: International Association of Scientific, Technical and Medical Publishers. www.stm-assoc.org/2015_02_20_STM_Report_2015.pdf

Wilsdon, James i in. 2015. The Metric Tide: Report of the Independent Review of the Role of Metrics in Research Assessment and Management. London: HEFCE. DOI:

10.13140/RG.2.1.4929.1363 
Krystian Szadkowski - adiunkt w Instytucie Filozofii Uniwersytetu im. Adama Mickiewicza w Poznaniu, badacz w Centrum Studiów nad Polityką Publiczną oraz sekretarz Katedry UNESCO Badań Instytucjonalnych i Polityki Szkolnictwa Wyższego. Redaktor naczelny czasopisma „Praktyka Teoretyczna”, a od 2015 r., redaktor wykonawczy czasopisma „Nauka i Szkolnictwo Wyższe”. W latach 2010-2013 stypendysta Fundacji Marie Curie-Skłodowskiej, zatrudniony na stanowisku młodszego badacza w Instytucie Badawczym Education International, globalnej centrali nauczycielskich i akademickich związków zawodowych w Brukseli. Współredaktor książek: W sprawie Agambena. Konteksty krytyki (2010), Wieçna radość. Ekonomia polityczna społecznej kreatywności (2011), Edu-factory. Samoorganizacja i opór w fabrykach wiedzy (2011). Autor niedawno wydanej książki Uniwersytet jako dobro wspólne. Podstawy krytycznych badań nad sækolnictwem myżşym (2015).

\section{DANE ADRESOWE:}

Centrum Studiów nad Polityką Publiczną UAM

ul. Szamarzewskiego 89c

60-569 Poznań

EMAIL: krysszad@amu.edu.pl

CYTOWANIE: Szadkowski, Krystian. 2015. Postoperaistyczne spojrzenie na prace produkcyjną i nieprodukcyjną w nauce i szkolnictwie wyższym. Praktyka Teoretycz̨na 4(18): 62-92.

DOI: $10.14746 /$ prt.2015.4.3

\section{AUTHOR: Krystian Szadkowski}

TITLE: Postoperaist perspective on productive and unproductive labour in science and higher education

ABSTRACT: This text starts with the inadequacy of the dispossession theory for the analysis of the relationship between publishing capital and academic labor; it is necessary to develop a Marxian theory of productive and unproductive labor within the field of science and higher education. For this purpose, a post-operaist perspective on productive labor has been proposed, which makes it possible to analyse the phenomenon of contemporary subsumption of academic labor under capital, as well as resistance against it. The essence of this approach is rooted in an exposition of the dual perspective on Marxist categories of the critique of political economy. It is used here to approximate the concept of directly productive academic labor, as well as to point out its apparent limitations. The next step is to present a view on the systemic productivity of academic labor. This is the only way to address the issue of truly productive academic work in the Marxian sense, and the obstacles on the way to its full implementation, 
the key to which is the smooth functioning of capitalist measures within the field of science and higher education.

KEYWORDS: capital, productive/unproductive labor, academic labor, higher education, Marx 